\title{
Never had it so good?
}

\section{The Blair-Brown era has been a golden one for British science.}

$\Lambda$ nyone remember Save British Science? Twenty-one years ago, with universities in decline, laboratories in disrepair and academics packing their bags to head in the general direction of California, there was plenty of meat for the pressure group of that name to sink its teeth into. Today, the shrill sound of the name seems almost quaint.

No one would claim that British scientists today live in the best of all possible worlds, but there is no denying that, in many disciplines and departments, British science is in rather good shape, thank you very much. The country's universities have their problems but do well in international comparisons; research-intensive industries, such as pharmaceuticals, are prospering; and scientific leaders have a respected voice in national affairs. In 2005, Save British Science accordingly transformed itself into the rather more staid-sounding Campaign for Science and Engineering.

This happy state of affairs is one success for which Tony Blair, Britain's outgoing prime minister, and Gordon Brown, set to be his successor, can share credit - a success that the political world has not fully appreciated. Blair is not viscerally grabbed by science in the same way as $\mathrm{Al}$ Gore, but he is attracted by its inherent modernity, and has been steadfast in supporting Brown, the chancellor of the exchequer, in his deeper devotion to the issue.

Brown sees science and innovation at the very core of his national modernization project. As the Labour Party's spokesman on trade and industry soon after Save British Science was set up, he read, absorbed and planned. The outcome was the decision by 'New Labour', which he and Blair brought into being, to ditch the party's traditional attachment to applied research and industrial policy, and concentrate instead on backing basic science while creating a better climate for entrepreneurial innovation.

Blair announced on 10 May that he was resigning; on 27 June, barring acts of God, Brown will succeed him. (The bookmaker William Hill, to which Nature regularly turns on matters of political prognosis, is already paying out to punters with money wagered on Brown's ascendancy.) For science, this should mean more of the same. Brown has made it crystal clear that the government's commitment to investment must continue. One of his last acts at the Treasury has been to publish a ten-year spending plan that foresees substantial further growth in research spending.

However, there are two notable concerns on the horizon. One is that, faced with day-to-day responsibility for everything from hospital waiting lists to the occupation of Iraq, Brown is bound to leave decisions about science and innovation in the hands of colleagues. Few senior Labour politicians other than Brown have shown much interest in, or commitment to, science, so this change could bode ill.

Second, Brown's electoral prospects are less bright than those of Blair before the past three elections. Brown leads a party with which the electorate is disenchanted against a Conservative opposition that has found new appeal under the leadership of David Cameron. There is scant indication that the Conservatives are champing at the bit to invest money in the universities. Instead, they are likely to seek reductions in public spending in almost all areas that are less politically sensitive than health or schools - areas such as scientific research.

This puts a new onus on British researchers. Their current happy state is not of their own making. With the plucky and laudable exception of Save British Science, the research community has done little to improve its lot. Now it should give its support to the renamed Campaign for Science and Engineering, and do what it can to maintain the happy status quo.

Researchers should make it a priority to communicate their accomplish-
"There is scant indication that the Conservatives are champing at the bit to invest money in the universities." ments to politicians of all parties and to the public at large, thus justifying the generosity they have received. The scientists closest to the levers of power should identify those among their number best suited to the key jobs, such as directorgeneral of the research councils, that can exert real budgetary influence. And the community as a whole should be building alliances - with industry, consumers (especially of healthcare), environmentalists and everyday geeks - that will sustain political support for science in the long term. British science has had the good fortune to be saved by far-sighted politicians. But its future lies in its own hands.

\section{Health cheques}

\section{Philanthropy offers a valuable approach to funding.}

$\mathrm{n}$ scientific funding, as in agriculture, monoculture is risky. However well-meaning and diligent its paymasters may be, a field that has only one source of funding runs the risk of missing opportunities and succumbing to a shared perception of what is possible and what is not. Diversity is thus to be prized. The current increase in scientific funding from individual philanthropists, private foundations and non-profit organizations, particularly in biomedical science (see page 248 and www.nature.com/news/specials/philanthropy), is a welcome development in a field that is largely dominated by governments.

With this new money come new attitudes. Philanthropists tend to have strong and clear ideas about what should be funded. If, as many of the new wave did, they made their money in industries that are themselves driven by research, they will often want to delve deeper into what scientists are actually doing than the foundations 
of yesteryear, either out of pure intellectual engagement or a desire to micromanage.

Philanthropic organizations tend to be interested in particular outcomes, rather than in simply funding the most academically interesting question that presents itself. They may take a more business-like approach, too, demanding milestones and results. And they can show a greater readiness to turn off the funding if these things are not forthcoming - or, in some cases, simply if the stock market takes a tumble.

The mixture of risk tolerance and accountability seen in some foundations, particularly those concerned with a specific disease, may seem contradictory, but it need not be so. What matters to the administrators who dole out the cash is normally not success per se, but demonstrated diligence in following the risky strategy set down. This level of accountability can make some researchers uncomfortable (see page 252). If basic researchers expect to benefit from these disease-focused foundations, they need to make a compelling case that their studies offer a real chance of progress towards a cure, and to document the way those chances play out.
This does not mean that the donor is always right, however. There are real risks that some areas of biomedical research could be dominated by a few rich people and the boards on which they sit, with little guidance from scientific consensus or expertise. Philanthropic groups need to think carefully about how best to award money, and to realize that no single strategy will succeed in every case. What's right for Huntington's disease, where a faulty gene has been named and shamed, may be wrong or premature for something more complex, such as autism. Rushing into the wrong strategy will merely waste time and money.

In the end, though, it is the philanthropists' money to waste. They would obviously be wise to make sure that the money is well spent, but they cannot always be stopped from other courses. Rather, it is for the scientists who stand to benefit from such largesse to ask themselves whether the money on offer is worth the risks of the course being prescribed. By doing so, and by helping donors identify the most pressing scientific questions relevant to their remit, the scientific community can help make the most of the new diversity offered by the philanthropy boom.

\section{Blurred vision}

\section{In the end, the European Institute of Technology will not be worthy of its title.}

t could have been inspiring. Imagine a university set up to educate some of the best students from Europe and beyond, and to provide a home for the world's most creative researchers in the natural sciences and engineering. It would be an institution with an outstanding new campus, benefiting from annual revenues of at least $€ 500$ million (US\$700 million) - a pinnacle scholars would aspire to and entrepreneurs would move to be close to.

That is what the European Institute of Technology (EIT) might have been. It was what was implicit in the idea that the president of the European Commission, José Manuel Barroso, put forward under that name in 2005. The proposal that now goes by the name of the EIT is a paltry thing by comparison - a small, central, administrative executive that would select 'knowledge and innovation communities' (KICs) to fund research in promising-sounding areas. The KICs would be distributed networks made up of 'partnerships' between organizations in the education, research and business sectors, and would confer postgraduate degrees. The commission would contribute $€ 2.4$ billion between 2008 and 2013 .

An expert group commissioned by the European Parliament to analyse this proposal recommended a different way forward last month. In this vision, too, there is no central EIT - but the KICs become genuine bricks-and-mortar institutes, 20 or so of them, each with 300-odd scientists, located in regions where there is already established research strength.

Parliament, however, seems not to be taking its experts' advice. Both it and the European Council - the two decision-making bodies of the European Union - are likely to approve the commission's lack-lustre notion of virtual networks. And both are downplaying the element of education, toying with the idea that the EIT and its components might offer some sort of watered-down postgraduate diploma without the clout of a PhD.

So Europe will get yet another virtual industry-academic network, to sit alongside the Framework Programme's Networks of Excellence, the EUREKA clusters and a welter of other variations on the theme. This shop-worn notion of the EIT has little if any support among researchers. Industry, too, finds it uninteresting.

This delocalized compromise marks a distressing loss of nerve. Europe has a demonstrated ability to deliver enduring world-class research institutions: the particle-physics laboratory CERN and the European Molecular Biology Laboratory stand as evidence. It has shown a willingness to invest in research excellence for its own sake, independent of political agendas - witness the fledgling European Research Council, flooded with applications in its first round of awards. If it chose to, why should the world's largest economy not set up a unitary engineering powerhouse to rival the Massachusetts Institute of Technology, with all the benefits that such scale and ambition confer?

This pitiable state of affairs highlights much of what is wrong with pan-European politics. One fundamental problem is that of 'subsidiarity', a principle embedded in the European Union's foundational Treaty of Rome that requires the commission to steer clear of functions that individual countries are considered to do well enough already, including the award of academic qualifications. Another is a chronic reluctance to commit to bricks and mortar for research.

The German presidency is keen to launch a 'test KIC' next year, specializing in energy efficiency or climate change. It will be a long way from a world-leading academic institution that would have inspired Europe's young people and stimulated its economies. The financial and constitutional challenges involved would have been undeniably great. But the outcome could have been fully worthy of the academic heritage that Europe possesses, and may have stimulated it to new heights. Is that vision now dormant? Or is it dead? 